\title{
Salivary uric acid - the friend hidden behind the curtain
}

\author{
Acidul uric salivar - prietenul ascuns în spatele cortinei \\ Alexandra TOTAN ${ }^{1}$, Marina MELEŞCANU-IMRE², Maria GREABU ${ }^{1}$, Cosmin TOTAN ${ }^{3}$ \\ ${ }^{1}$ Disciplina Biochimie, Facultatea de Medicină Dentară, UMF „Carol Davila“, Bucureşti, România \\ 2 Facultatea de Medicină Dentară, UMF „Carol Davila“, Bucureşti, România \\ ${ }^{3}$ Disciplina Chirurgie Oromaxilofacială, Facultatea de Medicină Dentară, \\ UMF „Carol Davila“, Bucureşti, România
}

\begin{abstract}
Saliva is the first line of defense against oxidative stress. The salivary antioxidant system includes different categories of molecules, the most important of these being the uric acid molecule and the salivary peroxidase system, both hydrosoluble.

Our experimental data revealed significant reductions in salivary uric acid levels in the context of severe oral conditions, such as periodontal disease, oral lichen, oral cancer, compared to controls.

The analysis of our results led us to the conclusion that chronic inflammation, as well as premalignant and/or malignant lesions, can significantly reduce the salivary antioxidant potential, supported primarily by uric acid, thus causing the oral environment to become more vulnerable to oxidative stress, which explains the progression of oral affections and the emergence of resistance to treatment.
\end{abstract}

Keywords: uric acid, oxidative stress, saliva

\section{REZUMAT}

Saliva reprezintă prima linie de apărare impotriva stresului oxidativ. Sistemul antioxidant salivar include diferite categorii de molecule, cele mai importante dintre acestea fiind molecula de acid uric şi sistemul peroxidazic salivar, ambele hidrosolubile.

Datele noastre experimentale au evidențiat reduceri semnificative ale nivelului acidului uric salivar în contextul unor afecțiuni orale severe, cum ar fi boala parodontală, lichenul plan oral, cancerul oral, comparativ cu loturile control.

Analiza rezultatelor noastre ne-a condus la concluzia că inflamația cronică, precum şi leziunile premaligne şi/sau maligne pot reduce semnificativ potențialul antioxidant salivar, susținut în primul rând de acidul uric, determinând astfel ca mediul oral să devină mult mai vulnerabil la stresul oxidativ, ceea ce explică progresia afecțiunilor orale şi apariția rezistenței la tratament.

Cuvinte cheie: acid uric, stres oxidativ, salivă 


\section{INTRODUCERE}

Prima utilizare semiempirică a antioxidanților a avut loc în secolul al XIX-lea, când s-au folosit mai multe molecule pentru a controla producția de cauciuc și pentru a preveni fenomenul de „oboseală a polimerilor" (1).

Chimia ascunsă în spatele efectelor antioxidante este reprezentată de blocarea radicalilor peroxil și de reducerea hidroperoxizilor $(1,2)$.

Saliva este privită ca fiind primul fluid biologic care intră in contact cu xenobioticele ingerate (ca alimente, băuturi) sau inhalate (fum de țigară CS) și microorganismele. În realitate, saliva reprezintă și prima linie de apărare împotriva stresului oxidativ (SO) (3).

În cursul evoluției vieții aerobe s-au dezvoltat în salivă mecanisme complexe de apărare împotriva atacurilor chimice, care au constituit aparatul de apărare antioxidantă $(3,4)$.

Sistemul antioxidant salivar include diferite categorii de molecule. Cele mai importante dintre acestea sunt molecula de acid uric și sistemul peroxidazic salivar, ambele hidrosolubile (3-5). Este important de remarcat faptul că rolul antioxidant al moleculei de acid ascorbic în saliva ocupă un loc secundar (3-5).

\section{CINE ESTE, DE FAPT, ACIDUL URIC?}

2,6,8-trioxipurina, cunoscută sub numele de acid uric, reprezintă un derivat heterociclic al purinei, cu o greutate moleculară de $158 \mathrm{Da}$. Acidul uric a fost identificat pentru prima dată ca o componentă a pietrelor vezicii urinare de către farmacistul suedez Scheele, în 1776 (6). În mod remarcabil, la primatele superioare și la oameni, acidul uric reprezintă produsul final de degradare a nucleotidelor purinice (adenină și guanină) (6), spre deosebire de restul animalelor, la care degradarea purinelor continuă până la alantoină. Nucleotidele purinice reprezintă principalii constituenți ai acizilor nucleici și ai unor compuși macroergici (ATP, GTP) (7).

În mod surprinzător, saliva a fost folosită în scopuri de diagnosticare cu peste 2.000 de ani în urmă (8). În medicina tradițională chineză, saliva și sângele sunt frați și se crede că au aceeași origine (8).

Câteva dintre numeroasele avantaje ale salivei ca fluid biologic de diagnostic sunt (8):

- colectare ușoară și fără stres

- o mare stabilitate a probelor și posibilitatea stocării pe termen lung

- risc minim de contaminare a personalului medical și pacienților
- corelație semnificativă în parametrii sângelui și salivă, în unele cazuri și sensibilitate mai mare față de sânge

\section{ACIDUL URIC - UN POSIBIL VIITOR MARKER SALIVAR IN PATOLOGIA ORALĂ?}

În contextul cavității orale, acidul uric reprezintă cu adevărat cel mai important antioxidant salivar, asigurând aproximativ $70 \%$ din capacitatea antioxidantă totală (TAC) a salivei (3-5). Antioxidanții liposolubili, purtați de lipoproteine, acidul ascorbic și glutationul nu asigură mai mult de $10 \%$ din TAC salivară (3-5).

Corelația existentă între nivelurile de acid uric din salivă și plasmă indică faptul că acidul uric salivar provine din sânge (3-5).

Orice răspuns fiziologic excesiv, prelungit sau eronat la o provocare specifică reprezintă o condiție descrisă de către Forman ca stres (2). 0 astfel de condiție duce la modificarea prelungită a homeostaziei, fenomen ce va fi perceput ca boală (2). În acest sens, toate bolile destul de diferite, cum ar fi cancerul, maladiile neurodegenerative, maladiile autoimune, fibroza hepatică și pulmonară etc., ar trebui considerate ca exemple de activare necorespunzătoare sau prost controlată a răspunsului la un semnal exterior specific (2). Răspunsul la acțiunea agenților ce induc leziuni oxidative depinde de capacitatea anumitor celule de a preveni sau de a repara aceste leziuni (2).

Elementele de bază ale procesului inflamator sunt reprezentate de reacții complexe ale căror ținte sunt eliminarea stimulului, repararea leziunilor provocate prin procese de proliferare celulară și angiogeneza și distrugerea celulelor afectate ireversibil (2). Important de observat este faptul că toate evenimentele inflamatorii sunt orchestrate de o serie de căi esențiale de semnalizare celulară. Aceste căi de semnalizare funcționează prin reacțiile de oxidare ale unor senzori proteici, care vor acționa fie ca traducători de semnal, fie ca efectori (2). Răspunsul la apariția leziunilor moleculare și reacțiile inflamatorii evoluează, de obicei, prin generarea de specii chimice cu caracter electrofil, inclusiv oxidanți, care vor produce un al doilea nivel de semnalizare și vor conduce la restabilirea homeostaziei statusului redox (2).

În cadrul proceselor inflamatorii, „,puseul respirator" de la nivelul macrofagelor reprezintă o sursă importantă de specii reactive ale oxigenului (SRO). Aceste SRO vor acționa la nivelul fagozomilor ca agenți oxidanți toxici pentru microorganisme și celule neoplazice (8). În ciuda faptului că SRO au timpi de înjumătățire extrem de scurți, în 
concentrații mari, aceste specii moleculare pot provoca leziuni substanțiale componentelor celulare, în contextul reacțiilor inflamatorii acute sau cronice (8).

Astfel, echipa noastră de cercetare și-a îndreptat atenția asupra determinării acidului uric salivar în contextul celei mai răspândite boli inflamatorii cronice, care afectează persoanele de toate vârstele - boala parodontală (9). Ne-am gândit să explorăm saliva știind că acest fluid biologic asigură o linie esențială de apărare antioxidantă.

Antioxidanții joacă roluri cheie pe scena afecțiunilor sistemice și orale induse de stresul oxidativ (10). În ceea ce privește studiul nostru, valorile concentrațiilor acidului uric au fost semnificativ mai scăzute la pacienții diagnosticați cu parodontopatii, comparativ cu grupul control (11). De asemenea, și în cazul altor doi membri ai sistemului de apărare antioxidantă salivară (TAC și peroxidaza salivară), am obținut valori semnificativ scazute la pacienții cu parodontopatii versus control. Mai mult, rezultatele noastre au ilustrat o corelație pozitivă, semnificativă între nivelul acidului uric salivar și ceilalți doi parametrii (TAC, peroxidaza salivară), punând în lumină încă o dată importanța acidului uric pe scena apărării antioxidante în salivă (11).

De asemenea, în cadrul grupului de pacienți cu boală parodontală, rezultatele noastre au evidențiat o corelație negativă semnificativă între concentrațiile acidului uric salivar și metaloproteaza 8 (MMP-8), marker ce ilustrează nivelul de degradare a colagenului (11).

Continuând să rămânem în constelația fascinantă a evenimentelor moleculare din procesul inflamator cronic, ar trebui menționate rezultatele noastre privind nivelul acidului uric salivar în contextul lichenului plan oral (LPO) (12). Organizația Mondială a Sănătății (OMS) a clasificat LPO ca fiind o „afecțiune potențial malignă“ și a sugerat că pacienții cu această afecțiune trebuie monitorizați atent (13).

LPO reprezintă o afecțiune cronică inflamatorie orală cu etiologie misterioasă, posibil autoimună. Această afecțiune orală este caracterizată prin keratinizarea epitelială anormală (14). Substratul molecular al patogenezei LPO este foarte complex și încă neelucidat (14).

Studiind literatura de specialitate, este evident faptul că foarte puține studii au explorat potențialul sistemelor antioxidante și al acidului uric din salivă în contextul LPO. Prin urmare, în studiul nostru ne-am propus să investigăm posibilitatea identificării și a determinării cantitative a unor biomarkeri salivari la pacienții diagnosticați cu această afecțiune (acid uric, TAC, peroxidaza salivară, CTX I, MMP-8) (12).
Datele noastre experimentale au reliefat o scădere semnificativă a valorilor concentrațiilor acidului uric salivar, în cadrul grupului de pacienți cu LPO, comparativ cu lotul control (12). Aceeași scădere semnificativă s-a înregistrat și în cazul TAC și al peroxidazei salivare (12).

Rezultatele noastre experimentale subliniază faptul că această scădere semnificativă a parametrilor ilustrativi pentru capacitatea de apărare antioxidantă ar putea fi datorată instalării unui stres oxidativ oral intens, în contextul reacțiilor inflamatorii cronice locale (12). Interesant este, de asemenea, și faptul că am observat o corelație negativă semnificativă a nivelului acidului uric salivar cu activitatea MMP-8 salivar (marker de inflamație) (12). Datele noastre experimentale reliefează încă o dată faptul că acidul uric nu este doar un simplu produs de degradare metabolică. Datorită informațiilor complexe pe care le aduce, mai ales dacă este determinat alături de markeri de inflamație și/sau de degradare a colagenului, acidul uric salivar promite să devină un important biomarker în contextul afecțiunilor orale.

Având în vedere capacitatea sa antioxidantă, acidul uric salivar ar trebui privit cu interes și în contextul cancerului oral. Datorită rolului complex al SRO în cadrul mecanismelor moleculare ale cancerului, am considerat foarte interesant și provocator studiul markerilor salivari, în special al acidului uric, în contextul cancerului oral (15). Datele noastre experimentale au arătat că malignitatea orală este asociată și cu o reducere semnificativă a potențialului antioxidant salivar, ilustrată de scăderea concentrației acidului uric salivar la pacienții cu tumori maligne, comparativ cu grupul control (15).

În literatura de specialitate există studii foarte interesante care au demonstrat că modificările echilibrului redox celular sau extracelular reprezintă evenimente cheie ale inițierii și progresiei proceselor maligne (16).

Mai mult, rezultatele noastre ne-au condus la concluzia că inflamația cronică, precum și leziunile premaligne și/sau maligne pot reduce semnificativ potențialul antioxidant salivar, susținut în primul rând de acidul uric, determinând astfel ca mediul oral să devină mult mai vulnerabil la stresul oxidativ (15).

Datorită proximității anatomice a salivei cu țesuturile orale, în viitor trebuie susținute și mai intens cercetările care au ca scop elucidarea mecanismelor moleculare de apărare antioxidantă, fără a se neglija rolul complex al acidului uric salivar.

Conflict of interest: none declared Financial support: none declared 


\section{BIBLIOGRAFIE}

1. Surh YJ. Cancer chemoprevention with dietary phytochemicals. Nat Rev Cancer 2003, 3, 768-780.

2. Forman HJ, Kelvin, Davies JA, Fulvio Ursini F. How Do Nutritional Antioxidants Really Work: Nucleophilic Tone and ParaHormesis Versus Free Radical Scavenging in vivo. Free Radic Biol Med. 2014, 66

3. Greabu M, Battino M, Totan A, Mohora M, Mitrea N, Totan C, Spinu T, Didilescu A. Effect of gas phase and particulate phase of cigarette smoke on salivary antioxidants. What can be the role of vitamin $\mathrm{C}$ and pyridoxine? Pharmacol Rep. 2007, Sep-Oct, 59(5), 613-8.

4. Battino M, Greabu M, Totan A, Bullon $P$, Bucur A, Tovaru S, Mohora M, Didilescu A, Parlatescu I, Spinu T, Totan C. Biofactors, 2008, 33(4), 301-10.

5. Greabu M, Didilescu A, Puiu L, Miricescu D, Totan A. Salivary antioxidant biomarkers in non-ferrous metals mine workers - a pilot study. J Oral Pathol Med. 2012, 41(6), 490-3.
6. Chen C, Lu JM, Yao Q. HyperuricemiaRelated Diseases and Xanthine Oxidoreductase (XOR) Inhibitors: An Overview. Med Sci Monit, 2016; 22 : 2501-2512.

7. Greabu M, Totan A. Tratat de chimie şi biochimie pentru Medicina Dentară, vol. I şi II. Editura Standardizarea, Bucureşti, 2010.

8. Greabu M, Totan A, Battino M, Mohora M, Didilescu A, Totan C, Spinu T. Cigarette smoke effect on total salivary antioxidant capacity, salivary glutathione peroxidase and gamma-glutamyltransferase activity. Biofactors. 2008, 33(2), 129-36.

9. Ridgeway EE. Periodontal disease: diagnosis and management. J Am Acad Nurse Pract 2000, 12, 79-84.

10. Niki E. Antioxidant capacity: which capacity and how to assess it? J Berry Res 2011, 1, 169-76.

11. Miricescu D, Greabu M, Totan A et al. Oxidative stress - a possible link between systemic and oral diseases. Farmacia, 2011, 59, 3.
12. Totan A, Miricescu D, Parlatescu I, Mohora M, Greabu M. Possible salivary and serum biomarkers for oral lichen planus. Biotech Histochem. 2015, 90, 7, 552-8.

13. Warnakulasuriya S, Johnson NW, Van der Waal I. Nomenclature and classification of potentially malignant disorders of the oral mucosa. J Oral Pathol Med, 2007, 36, 575-80.

14. Ismail SB, Kumar SK, Zain RB. Oral lichen planus and lichenoid reactions: etiopathogenesis, diagnosis, management and malignant transformation. J Oral Sci, 2007, 49, 89-106.

15. Radulescu R, Totan A, Calenic B, Totan C, Greabu M. Biomarkers of Oxidative Stress, Proliferation, Inflammation and Invasivity in Saliva from Oral Cancer Patients. Journal of Annalytical Oncology, 2015, 4,1.

16. Kumari S, Badana AK, Malla R. Reactive Oxygen Species: A Key Constituent in Cancer Survival. Biomark Insights., 2018, $6,13$. 